\title{
An investigation of early childhood education teachers' attitudes, behaviors, and views regarding the rights of the child
}

\author{
Cagla Banko-Bal ${ }^{*}$ (i) and Tulin Guler-Yildiz(i)
}

\section{*Correspondence:}

cagla.banko@hacettepe.

edu.tr

Hacettepe University, Ankara Turkey

\begin{abstract}
This study investigates the attitudes, behaviors, and views about the rights of the child of early childhood education (ECE) teachers in Turkey. A mixed-method sequential transformative design was used, and 205 ECE teachers' attitudes towards children's rights were analyzed using a quantitative questionnaire. Ten of these ECE teachers were then observed, and their views in terms of the rights of children were elicited through interviews. According to the findings, teachers' attitudes toward the rights of the child were positive; however, their behaviors and views were not compatible with most of these rights. While teachers were sensitive to the right to protection, they did not meet the requirements of the rights to development, growth, and participation or the principles of best interest and non-discrimination. Educating teachers about the rights of the child plays an important role in enhancing children's learning and the application of these rights. To support these rights, teachers need to properly understand the rights of the child, how to protect them, and how to reflect these rights in their practices.
\end{abstract}

Keywords: Early childhood education, Rights of the child, Teacher-child relationship, Right of participation

\section{Introduction}

It is important to realize that children's learning affects the future of society as well as children's individual lives. The welfare of a society depends on it using all facilities to raise and develop healthy children for whom society is responsible (Akyuz, 2000; Ucus, 2014). Children recognizing and using their rights is important for society because protecting and developing children's personalities and abilities requires protecting the rights of the child in all environments, especially at home and school (Ucus, 2014). Therefore, children need to be aware of their responsibilities and their rights as citizens, which only happens when children know their rights as stated in the United Nations Convention on the Rights of the Child (UNCRC) (Howe \& Covell, 2005).

The UNCRC is an international agreement accepted by 191 states in 1989. It protects the rights of children and provides a child-centered framework for the services related to children's development. The rights established in the UNCRC include both human rights and special rights of children. Three partly overlapping groups of rights included in the

(c) The Author(s) 2021. This article is licensed under a Creative Commons Attribution 4.0 International License, which permits use, sharing, adaptation, distribution and reproduction in any medium or format, as long as you give appropriate credit to the original author(s) and the source, provide a link to the Creative Commons licence, and indicate if changes were made. The images or other third party material in this article are included in the article's Creative Commons licence, unless indicated otherwise in a credit line to the material. If material is not included in the article's Creative Commons licence and your intended use is not permitted by statutory regulation or exceeds the permitted use, you will need to obtain permission directly from the copyright holder. To view a copy of this licence, visit http://creativeco mmons.org/licenses/by/4.0/. 
UNCRC are provision rights, protection rights, and participation rights (UNCRC, 1989). Provision rights are related to care, health, life, education, cultural life, and the arts. Protection rights include protection from neglect, abuse, violence, cruel and degrading treatment, discrimination, invasion of privacy, exploitation and hazardous work, armed conflict, invasive research, and ecological change. Participation rights can overlap and complement the other two groups of rights. They include the right to life and optimal development; having a name, identity, and family; respect for the child's evolving capacities; and the ability to express views freely, make decisions, and be heard (Alderson, 2008). In addition to these, states should consider the best interests of the child in all development strategies and implementation (UNCRC, 1989). The United Nations International Children's Emergency Fund (UNICEF) report about the implementation of the UNCRC in 12 countries (Australia, Belgium, Germany, Ireland, Norway, Spain, Canada, Denmark, Iceland, New Zealand, South Africa, and Sweden) shows that the implementation of the UNCRC is being taken seriously in various ways and with varying degrees of commitment in these countries. However, they could not fully implement the UNCRC and every country has its own ideal model for approaching implementation (UNICEF, 2012). Furthermore, Belgium, Norway, and Spain, which have incorporated the UNCRC, seem to be more likely to perceive children as rights holders and to build a culture to respect children's rights. It was also stated that there was a need for training and awareness on the UNCRC from legislation to case law and from policy development to service provision for children to implement the UNCRC effectively (UNICEF, 2012).

In 2004, the Committee on the Rights of the Child conducted a Day of General Discussion, which is periodically held to discuss a specific article of the Convention or a child rights theme and is open to the public. The topic of that day was "Implementing Child Rights in Early Childhood”. After this day, General Comment N0.7 was published. According to this General Comment, young children are holders of all rights enshrined in the Convention and early childhood is a critical period for the realization of these rights. The Committee's working definition of "early childhood" includes all young children from birth, throughout infancy, and during the preschool years, as well as during the transition to school (UNCRC, 2005).

At the 2010 World Conference on Early Childhood Care and Education, early childhood care and education was restated as a right and as a critical condition to support child development and welfare (UNESCO, 2010). In order for children to learn about their rights, the environment they live in should be appropriate for and supportive of both their and other people's rights (Howe \& Covell, 2005; Kepenekci, 1999). One of the environments in which children learn about their rights is school. Moreover, children learn about their rights by being team members, communicating with peers, expressing their views freely, defending their rights, and realizing their responsibilities as citizens in their schools (Howe \& Covell, 2005; Kepenekci, 1999; Ucus, 2014). Therefore, it is necessary for teachers to know the rights of the child in depth, to teach children about their rights, and to encourage them to use their rights (Howe \& Covell, 2005; Ucus, 2014). In addition, teachers should be aware of and meet children's needs like being loved and build a warm, high-quality, and successful atmosphere (Erden, 2005; Malmberg, 2008; Yoleri, 2014). In the early childhood period, it is important to protect the rights of the child by recognizing children's capacities and competencies as active subjects and 
protagonists and improving the development of extraordinary potential. To accomplish these tasks, adults who work with children in early childhood should take care in two particular areas: enabling security and confidence for children's physical, emotional, and social needs and meeting children's needs for affection, attention, containment, and care (as cited in Etchebehere \& De León, 2020).

Children become active learners and their abilities in critical thinking, decisionmaking, and cooperative learning increase when their participation is enabled and all activities are implemented in democratic ways (Covell \& Howe, 2011). The relationship between teachers and children also becomes warmer and more positive when participation is enabled. In addition, when children are more willing to participate in school activities, teachers' occupational exhaustion decreases (Covell \& Howe, 2011; Covell et al., 2009). Likewise, another study found that when teachers take children's views into consideration and give them responsibilities while decreasing their own roles in activities, they experience less occupational exhaustion and are more energetic and beneficial to children (Sebba \& Robinson, 2010). In their systematic review, Correia et al., (2020) found that teachers' pedagogically sensitive attitudes characterized by respect, attention, and trust in children's capacities are important to promote children's participation. Nah and Lee (2016) also stated that children's confidence, communication, and negotiation skills improve and teachers attend to and respect children's ideas, interests, and needs more when children's participation is enabled.

In light of these results, it can be said that recognizing the rights of children is beneficial for teachers and society as well as for children, and teacher-child interaction is influenced by teachers' attitudes and behaviors in terms of the rights of children. Children's social, emotional, cognitive, and physical development are predominantly shaped during the early childhood period, and learning in this period is permanent (Bredekamp, 2018; Trawick-Smith, 2010). In addition, children gain some skills during this period, like following rules, respecting others' rights, accepting differences, and interacting socially (Pianta \& Walsh, 1996; Reijntjes et al., 2006). It can, thus, be said that it is vital to recognize the rights of the child in the early years and to implement them in all settings for teaching children about their rights. Accordingly, examining early childhood education (ECE) teachers' attitudes, behaviors, and views related to the rights of children is also important.

\section{The rights of the child and ECE in Turkey}

In Turkey, the number of children under the age of 18 is about 26 million, and children make up about $31 \%$ of the population. This shows that children have an important place in the population (Turkish Statistical Institute, 2020). Turkey adopted the UNCRC in 1990, but the agreement was approved in 1994. Today, the Ministry of Family, Labor, and Social Policies is mainly responsible for following up on the implementation of rights. Other ministries, some national and international foundations, and various organizations also work to protect and implement the rights of the child, like the Ministry of National Education (MoNE), UNICEF, Save the Children, and the International Children's Center.

In 2012, the Ministry of Family and Social Policies published the National Strategy Document and Action Plan for the Rights of Children, 2013-2017. According to this 
report, the Ministry aimed to recognize the best interests of the child, to ensure that those take precedence over all benefits, and to ensure a culture of children's rights based on the rights of growth and development, protection, participation, and non-discrimination and developed strategic goals in accordance with these missions. However, the 11th Development Plan (2019-2022) showed that there were still some areas that needed improvement, like child poverty, child labor, violence against children, and early marriage. Furthermore, access to early childhood education in Turkey is at the lowest level among the Organisation for Economic Co-operation and Development (OECD) states (Ministry of Strategy and Budget, 2018).

ECE is not compulsory in Turkey. The schooling rate for children aged 4-5 is $45.7 \%$, and for children aged $5-6$, it is $58.8 \%$. There are two main models of early childhood education: institution-based and home-based models. Institutional models include the public and private schools affiliated with the MoNE for children aged 3-6 and the Ministry of Family, Labor, and Social Policies for children aged 0-3. While public schools are non-profit, private schools are for profit. There is a National Early Childhood Education Program for children aged 3-6 in public preschools prepared by the MoNE in 2013. Private preschools also use this program together with or without their own approaches. It has a manual, developmental, spiral, and eclectic structure and takes into account children's characteristics, interests, and needs as well as environmental conditions. Teachers primarily need to follow the requirements of the program, but they can also apply their own pedagogies with the program's guidance. In addition, it gives importance to democratic education and includes a statement about protecting the rights of the child for both themselves and others (MoNE, 2013). In addition, ECE Teachers Qualifications were published by the MoNE in 2017. Accordingly, ECE teachers should ensure children's health and physical needs and emotional safety, give importance to children's pleasure and enjoyment during the learning process, and create a warm and democratic classroom atmosphere. Furthermore, active participation, meeting individual needs, supporting interactions with others, and guiding children to implement their own plans were also emphasized.

\section{The current study}

The topic of the rights of the child has increasingly been discussed and studied since the publication of the UNCRC. However, studies show that more research is still needed on this subject (Correia et al., 2019; Quennerstedt, 2011; Urinboyev et al., 2016). Studies conducted in Turkey show that while teachers are aware of the rights of children and their attitudes towards these rights are positive, they need more education to support these rights (Akman \& Erturk, 2011; Dogan et al., 2014; Hareket \& Gulhan, 2016; Leblebici \& Celikoz, 2016; Nesliturk \& Ersoy, 2007). These studies were generally focused on the attitudes of teachers toward the rights of the child. However, there is no research simultaneously conducted on ECE teachers' attitudes, behaviors, and views regarding applying the rights of children in the classroom. Therefore, it is thought that there should be more research to reveal the situation of the rights of the child in educational settings. This study aimed to investigate ECE teachers' attitudes, behaviors, and views toward the rights of the child by examining teacher-child interactions during class activities. The 
main problem is "What are ECE teachers' attitudes, behaviors, and views regarding the rights of the child?" The research questions are as follows:

1. What are ECE teachers' attitudes toward the rights of the child, and do their attitudes differ according to their demographic characteristics (age, education level, professional experiences, type of school in which they work, having taken a course related to the rights of children, and the number of children in their classroom)?

2. How are the behaviors of ECE teachers in practice compatible with the rights of the child?

3. How are the views of ECE teachers in practice compatible with the rights of the child?

\section{Methodology}

To describe the problem statement more clearly, this study applied both qualitative and quantitative methods and is, hence, classified as a mixed methods study (Creswell, 2017). More specifically, this study has a sequential transformative design. The sequential transformative design has two phases: the initial phase can be either quantitative or qualitative, followed by a second phase that builds on the earlier phase. Researchers can give weight to either or distribute their focus evenly to both phases (Creswell, 2017). After data are collected, they are analyzed separately and then interpreted together (Creswell, 2017; Creswell \& Plano-Clark, 2015). In this research, quantitative data were first collected to examine teachers' attitudes. After analyzing these data, qualitative data were gathered and analyzed. Finally, the quantitative and qualitative data were integrated and discussed.

This study was implemented by two researchers, one of whom collected all data. This researcher's areas of study are the rights of the child, child abuse and neglect, and antibias education and she is a PhD student in the field of early childhood education. The role of this researcher was to administer questionnaires and to observe teachers and interview them. The other researcher is a professor in the same field. Both researchers developed the observation and interview forms and they wrote the manuscript together.

\section{Quantitative phase}

\section{Participants}

Participants were selected from public and private preschools located in Cankaya, Ankara. Cankaya is one of the more densely populated areas of the city. There are 120 public preschools and 172 private preschools in the Cankaya school district. The number of children in public preschools is 6524 and there are 7752 in private preschools. There are 536 teachers in the public schools and 640 in private schools (MoNE, 2020). The participants were selected using convenience sampling, in which participants who volunteer for the study and are easily accessible are included in the research (Johnson \& Christensen, 2014). Accordingly, 23 public preschools and 24 private preschools were visited to collect quantitative data.

While 256 teachers participated in the quantitative study during the first stage, 41 teachers did not answer some questions on the written questionnaire completely. Therefore, they were excluded. After analyzing the missing data, it was seen that the data were not distributed normally because of outliers. Thus, the data from 10 teachers who were 
detected as outliers were also excluded. Finally, 205 ECE teachers were determined to be appropriate for the quantitative study (Table 1).

Most teachers in this group were aged 20-29 and had undergraduate or graduate degrees and 1-5 years of professional experience. One hundred and twelve of them worked in private preschools while 93 worked in public preschools. The class sizes were generally between 11 and 15 children, and 130 teachers stated that they had not received any education about children's rights.

\section{Procedures}

The quantitative data to examine teachers' attitudes were collected from 205 teachers during the fall semester of 2016-2017. Before data were collected, administrators were given detailed information about the study in a face-to-face or phone meeting. If the administrators said it was appropriate for the study to be conducted with the teachers in their schools, the researchers met with the teachers and asked for volunteers. The researchers distributed the written questionnaires to volunteers, informed them of the purpose of the study and the questionnaires, and left the schools. The completed

Table 1 Demographic information for teachers in the quantitative phase

\begin{tabular}{|c|c|c|c|}
\hline Variables & Groups & Frequency $(n)$ & Percentage (\%) \\
\hline \multicolumn{4}{|l|}{ Age } \\
\hline & $20-29$ & 93 & 45 \\
\hline & $30-39$ & 61 & 30 \\
\hline & $40+$ & 51 & 25 \\
\hline & Total & 205 & 100 \\
\hline \multicolumn{4}{|c|}{ Educational background } \\
\hline & High school or associate & 88 & 43 \\
\hline & Undergraduate or graduate & 117 & 57 \\
\hline & Total & 205 & 100 \\
\hline \multicolumn{4}{|c|}{ Professional experience (years) } \\
\hline & $1-5$ & 85 & 41 \\
\hline & $6-10$ & 43 & 21 \\
\hline & $11-15$ & 28 & 14 \\
\hline & $16+$ & 49 & 24 \\
\hline & Total & 205 & 100 \\
\hline \multicolumn{4}{|c|}{ School type } \\
\hline & Public & 93 & 45 \\
\hline & Private & 112 & 55 \\
\hline & Total & 205 & 100 \\
\hline \multicolumn{4}{|c|}{ Taking a course related to the rights of the child } \\
\hline & Yes & 75 & 37 \\
\hline & No & 130 & 63 \\
\hline & Total & 205 & 100 \\
\hline \multicolumn{4}{|l|}{ Class size } \\
\hline & $5-10$ & 50 & 24 \\
\hline & $11-15$ & 73 & 36 \\
\hline & $16-20$ & 49 & 24 \\
\hline & $21-25$ & 33 & 16 \\
\hline & Total & 205 & 100 \\
\hline
\end{tabular}


questionnaires were collected at a time appropriate for the teachers. The researchers did not intervene with teachers during questionnaire completion to avoid affecting their responses. Teachers were also asked whether they would participate in the second phase of this study, in which they would be observed and interviewed. If they were willing, their contact information was collected for future use.

\section{Questionnaire for measuring attitudes toward the rights of the child}

To investigate teachers' attitudes toward the rights of the child, a questionnaire developed by Karaman-Kepenekci (2006) was used with one factor and 22 items scored on a 5-point Likert-type scale from "totally disagree" to "totally agree." Karaman-Kepenekci (2006) applied exploratory factor analysis with 35 items. The 13 items that had factor loadings lower than 0.35 were extracted and the 22 items with factor loadings between 0.361 and 0.714 were included in the scale. It was found that all items of the scale were loaded under one component. In addition, the item-total correlation coefficient ranged between 0.32 and 0.61 , the value of Cronbach's $\alpha$ was 0.85 , and the half-test reliability coefficient was 0.77 . In this study, Cronbach's $\alpha$ had a value of 0.76 . As values of $\geq 0.70$ are usually taken as indicating acceptable reliability (George \& Mallery, 2003), this questionnaire can be said to be reliable. The items of this questionnaire are not distributed into subcategories. However, the items cover the rights outlined in the UNCRC. Sample items are shown in Table 2.

\section{Data analysis}

To analyze the quantitative data, skewness and kurtosis values and the KolmogorovSmirnov test were used to determine the normality of the data. While a skewness value of -1.6 was found, kurtosis was found to be 4.02. In addition, the $p$-value was less than 0.05. Thus, nonparametric tests were used to analyze the data. The Mann-Whitney U test was used to compare data between two independent variables (educational background, school type, and taking a course related to the rights of the child), while the data of more than two independent variables (age, professional experience, and class size) were compared using the Kruskal-Wallis test.

\section{Qualitative stage}

\section{Participants}

For the qualitative data, two public preschools and two private preschools were visited. The public schools implemented only the national program. One of the private preschools used the Montessori approach in addition to the national program, while the

Table 2 Sample items of questionnaire for measuring attitudes toward the rights of the child

\begin{tabular}{ll}
\hline Item number & Items \\
\hline 1 & I believe that persons under 18 years of age have rights because they are children \\
8 & I think children should have the right to express their opinions in writing or drawing \\
13 & $\begin{array}{l}\text { The state should take the necessary precautions to protect, educate, and employ } \\
\text { handicapped children } \\
\text { I believe children should be protected from wars }\end{array}$ \\
\end{tabular}


other applied the national program and used STEAM activities and some other additional resources (Table 3).

Twelve teachers from among the 205 teachers in the quantitative stage volunteered for observations and interviews. A pilot study was completed with two teachers and then 10 teachers were included in the study. While four of these teachers were aged 40 or over, three of them were between 30 and 39 and the rest were between 20 and 29. Most of them (90\%) had an undergraduate degree. Their professional experience ranged from 2 to 32 years. Half of them worked in private kindergartens. Most of them $(60 \%)$ stated that they had not taken any course regarding the rights of the child. Their class sizes ranged from 13 to 23 students.

\section{Procedure}

Researchers began to collect the qualitative data during the spring 2017 semester. Twelve teachers stated that it was permissible for them to be observed and interviewed after implementing the questionnaire. Two teachers were observed as a pilot study and were interviewed to check the validity of the observation and interview forms. The other 10 teachers provided data for the qualitative study. After getting the necessary permission from school principals, teachers, and parents of the children, a working schedule was prepared with the teachers and the researchers started to collect the qualitative data. Each teacher was observed for one hour during two consecutive days by one of the researchers. Before observations, the researchers introduced themselves to the classes and then sat in a place where they would not distract the children's attention during class activities. After observations, the researcher conducted the interviews, the contents of which are described below. The interviews were done after the observations to avoid affecting the teachers' behaviors. Each interview was completed in 5-10 min using an audio recording device.

\section{Observation form}

To examine whether teachers' behaviors in practice were compatible with the rights of the child, an observation form was developed by the researchers. The items are based on the three P's (participation, provision, and protection rights) and the best interests of the child as per the UNCRC (1989), a literature review (Howe \& Covell, 2005; Koran, 2012; Lansdown, 2005; Osler \& Starkey, 1998; Shier, 2001), and the Child-Friendly School Manual (UNICEF, 2009) and Child Rights Toolkit (UNICEF, 2014). Based on these sources, 5 categories and 28 subcategories were developed and then examined by 5 experts who were specialists in early education, measurement, and evaluation. After changes based on these experts' evaluations, the 28 subcategories were reduced to 21 subcategories through removal or combination. A pilot study was then performed with two teachers by one of the researchers to examine item reliability. In this study, the items were analyzed for functional adequacy rather than studying the teachers' behaviors. To do this, one private school and one public school teacher were observed. After making the necessary corrections after observing the first teacher, the observation of the second teacher proceeded without problems and it was decided to finish the pilot study. Based on the pilot study, one item was considered inappropriate for observation, while three items needed to be added. After 


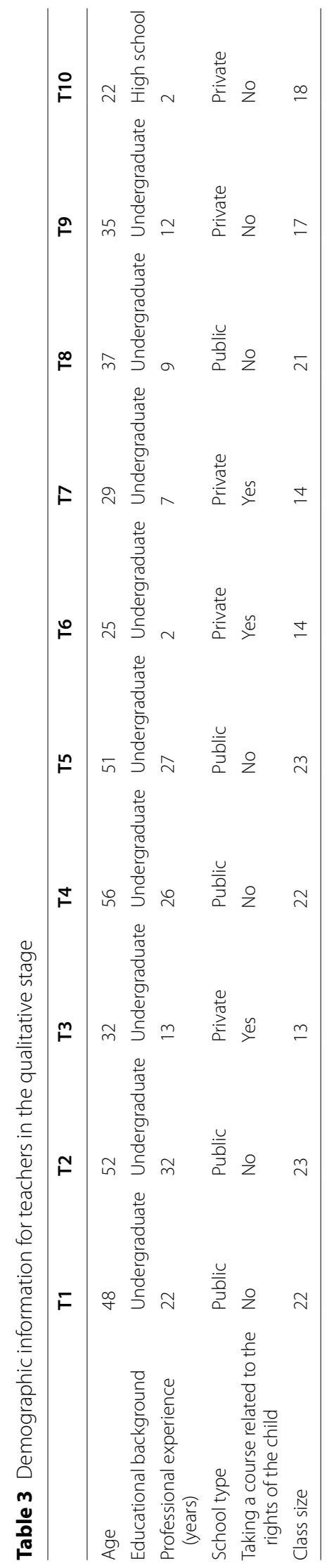


making all changes, the form comprised 5 categories and 23 subcategories and was ready to use. The categories and subcategories of the observation form are shown in Table 4 (further details about the observation form can be found in Additional file 1).

\section{Interview form}

The interview protocol was created by the researchers using the same sources as used for the observation form to investigate teachers' views regarding their practice and its compatibility with the rights of the child. Thus, four categories, 12 subcategories, and six questions were developed. After eight area experts evaluated the protocol, the questions were increased to 14 and a pilot was performed with two teachers. During the pilot phase, it was noted that two questions needed to be combined with other questions because teachers gave the necessary answers in response to the other questions. One question was added, and three questions were removed because researchers could not obtain satisfactory answers due to the teachers' lack of information or unwillingness to answer. The final version of the form included four categories, 12 subcategories, and 10 questions. The categories and subcategories of the interview form are shown in Table 5 (further details about the interview form can be found in Additional file 1).

Table 4 Categories and subcategories of observation form

\begin{tabular}{ll}
\hline Categories & Subcategories \\
\hline Category 1: Transparent and informative activities & 1.1. Taking children's views \\
& 1.2. Informing children about activities \\
Category 2: Activities based on voluntary participation & 1.3. Giving feedback during activities \\
& 1.4. Evaluation of activities \\
2.1. Including all children & 2.2. Respecting children's decisions \\
Category 3: Child-friendly activities & about participation \\
& 2.3. Offering different activities \\
& 3.1. Nondiscrimination \\
3.2. Caring for each child \\
3.3. Guiding each child \\
3.4. Answering all questions \\
3.5. Giving importance to children's ideas \\
3.6. Incorporating children's interests \\
3.7. Incorporating children's needs \\
3.8. Supporting play \\
4.1. Being tender \\
4.2. Talking clearly \\
4.3. Conversations about other subjects \\
4.4. No judgement \\
4.5. No comparing \\
4.6. No threatening \\
5.1. Preventing violence \\
5.2. Supporting sharing \\
\hline
\end{tabular}


Table 5 Categories and subcategories of interview form

\begin{tabular}{|c|c|}
\hline Categories & Subcategories \\
\hline \multirow[t]{4}{*}{ Category 1:Transparent and informative activities } & 1.1. Taking children's views \\
\hline & 1.2. Informing children about activities \\
\hline & 1.3. Giving feedback during activities \\
\hline & 1.4. Evaluation of activities \\
\hline \multirow[t]{3}{*}{ Category 2: Activities based on voluntary participation } & 2.1. Including all children \\
\hline & 2.2. Respecting children's decisions about participation \\
\hline & 2.3. Offering different activities \\
\hline \multirow[t]{3}{*}{ Category 3: Child-friendly activities } & 3.1. Guiding each child \\
\hline & 3.2. Supporting play \\
\hline & $\begin{array}{l}\text { 3.3. Having information about protecting children } \\
\text { from violence, abuse, and neglect }\end{array}$ \\
\hline \multirow{2}{*}{$\begin{array}{l}\text { Category 4: Supporting positive interactions between } \\
\text { children }\end{array}$} & 4.1. Preventing violence \\
\hline & 4.2. Supporting sharing \\
\hline
\end{tabular}

\section{Data analysis}

Data obtained from observations and interviews were analyzed using content analysis. The researchers observed the teachers with open-ended recording and, after that, they evaluated the behaviors of teachers and coded them in terms of the categories and subcategories of the forms as "applied", "sometimes applied", and "not applied”. Examples of teachers' behaviors were given for each subcategory. Both researchers separately read the records and coded the behaviors in terms of the categories of the observation form. In addition, after the interviews, the responses were transcribed verbatim. Researchers then coded their views in terms of the categories of the interview form. Finally, data from observations and interviews were analyzed. Furthermore, direct quotations were used to explain teachers' behaviors and views. Teachers were coded as TX (Teacher 1: T1, Teacher 2: T2, Teacher 3: T3, and so on).

\section{Ethical issues}

The necessary permits to collect data were first obtained from the ethics committee of the researchers' university, the MoNE, and the school principals. It was announced to all teachers that participation in the research was voluntary, and they were informed about the research. Volunteers signed a voluntary participation form to protect their rights related to the research. In addition, the children and their parents were also informed and their consent about the research was obtained through the class teachers. The researchers introduced themselves to the children and verbally obtained their permission to conduct the study in their classroom. Afterwards, the researcher sat in a place where the children and teacher would not be disturbed and did not intervene in the learning process during the activities. Data were collected from November 2016 to July 2017 . 


\section{Validity and reliability}

The researchers tried to control all factors that might affect validity and reliability during all stages of the process. In the qualitative stage, validity entailed observing the topics at hand and being objective. To improve internal validity, the researchers first reviewed related studies (Howe \& Covell, 2005; Koran, 2012; Lansdown, 2005; Osler \& Starkey, 1998; Shier, 2011; UNICEF, 2009, 2014). By performing a literature review, a conceptual framework was established and the items were determined. After that, these items were examined by area experts and their suggestions for changes were applied. Pilot studies were then performed and necessary additions, exclusions, and corrections were made. The observation and interview forms were then considered ready for use. Observations were made on consecutive days to avoid prejudicing the researchers and teachers.

To ensure reliability, one researcher from this study and another independent researcher observed three teachers and analyzed the data separately. After that, the intercoder reliability formula suggested by Miles and Huberman (1994) of "Reliability= number of agreements/total codes" was applied. According to Miles and Huberman, reliability holds if the value obtained is $70 \%$ or above. This value was $77 \%$ for observations and $75 \%$ for interviews, so it was concluded that the data were reliable. As Wolcott (1990) states, reliability can be improved by giving direct quotations, and some direct quotations were therefore included in the results. These direct quotations were translated without any changes and their compatibility in English was checked by an expert on English.

\section{Results}

In this study, the first aim was to examine ECE teachers' attitudes toward the rights of the child and how these attitudes correlated with the teachers' demographic characteristics. Results indicated that teachers' attitudes were substantially positive $(M=105, \mathrm{sd}=5.4)$ (Table 6). The highest possible score on the questionnaire was 110. Therefore, it can be said that teachers' attitudes toward the rights of the child were positive. In addition, the items related to protection of children from abuse, neglect, substance use, and war were most frequently marked as "totally agree".

Teachers' age $\left(\chi^{2}(2)=0.952 ; p>0.05\right)$, professional experience $\left(\chi^{2}(3)=2.4 ; p>0.05\right)$, and class size $\left(\chi^{2}(3)=7.42, p>0.05\right)$ were not associated with meaningful differences in their attitudes toward the rights of children (Table 7). Furthermore, there were no meaningful differences in attitudes toward the rights of children in terms of school type ( $U=4625$; $p>0.05)$ or taking a course related to the rights of children $(U=4405.5 ; p>0.05)$ (Table 8). The education level of the teachers was associated with a meaningful difference in attitudes $(U=4129 ; p<0.05)$, as the mean score of teachers who had an undergraduate or graduate degree was higher than that of teachers who only graduated from high school or had an associate's degree.

Table 6 Mean of responses to questionnaire for measuring attitudes toward the rights of the child

\begin{tabular}{llllll}
\hline & $n$ & $M$ & Std. dev & Min & Max \\
\hline Total & 205 & 105 & 5.4 & 78 & 110 \\
\hline
\end{tabular}


Table 7 Results of the Kruskal-Wallis Test

\begin{tabular}{|c|c|c|c|c|c|c|}
\hline Factors & Variables & $n$ & Mean & St. dev & $x^{2}$ & $p$ \\
\hline \multirow[t]{3}{*}{ Age } & $20-29$ & 93 & 98.74 & 2 & 0.952 & 0.621 \\
\hline & $30-39$ & 61 & 105.26 & & & \\
\hline & $40+$ & 51 & 108.07 & & & \\
\hline \multirow{4}{*}{$\begin{array}{l}\text { Professional experi- } \\
\text { ence }\end{array}$} & $1-5$ & 85 & 101.62 & 3 & 2.4 & 0.494 \\
\hline & $6-10$ & 43 & 99.49 & & & \\
\hline & $11-15$ & 28 & 94.13 & & & \\
\hline & $16+$ & 49 & 113.55 & & & \\
\hline \multirow[t]{4}{*}{ Class size } & $0-10$ & 50 & 91.74 & 3 & 7.245 & 0.06 \\
\hline & $11-15$ & 73 & 95.59 & & & \\
\hline & $16-20$ & 49 & 116.48 & & & \\
\hline & $21-25$ & 33 & 116.44 & & & \\
\hline
\end{tabular}

Table 8 Results of the Mann-Whitney U Test

\begin{tabular}{llrrlll}
\hline Factors & Variables & $n$ & Mean rank & Sum of ranks & $U$ & $p$ \\
\hline Educational background & High school or associate & 88 & 91.42 & 8045 & 4129 & $0.015^{*}$ \\
& Undergraduate or graduate & 117 & 111.71 & 13,070 & & \\
School type & 93 & 109.27 & 10,162 & 4625 & 0.166 \\
& Public & 112 & 97.76 & 10,953 & & \\
Taking a course related to & Private & 75 & 96.74 & 7255.5 & 4405.5 & 0.248 \\
the rights of the child & No & 130 & 106.61 & $13,859.5$ & & \\
& & & & &
\end{tabular}

${ }^{*} p<0.05$

After the quantitative stage examining the teachers' attitudes toward the rights of the child using the questionnaire, 10 teachers' behaviors and views were assessed in the qualitative stage of the study to investigate whether they were compatible with the rights of the child or not. The findings from observations and interviews are presented below.

\section{Category 1: Transparent and informative activities}

Among observations and interviews, T9 mentioned in the interview that she elicited children's ideas about what they expected during the day. T3 also listened to the children's ideas and offered them some options to choose among different activities. Other teachers conducted some activities that they had planned earlier. Most teachers said they decided on these activities based on the children's ages and interests without asking them. In addition, they considered the children's developmental characteristics as incorporated into the National ECE Program (MoNE, 2013). T1's views about preparation for activities were stated as follows:

T1: I consider the ages of the children, the activities they would like, being active and passive. Since I think language development is important, I include more Turkish language activities, as much as I can.

Before starting activities, T9 and T3 talked with the children about the activities and discussed what they would do, considering their roles and responsibilities. T1 stated that she gave information about the activities they would do together. In observations, she 
gave students the names and rules of activities, but the rules were not discussed with the children; rather, she preferred to simply read these rules. The other teachers gave limited information before starting activities, saying the name of the activities or giving brief information about the steps. They did not talk about the roles and responsibilities in detail; they read them without any discussion. In this regard, T4 gave the following statement:

T4: I explain the activities related to the subject of the day. Today, I was going to make an envelope, I looked, we didn't have time. I explained... about it. I was going to sing the Postman song. I saw my deficiencies immediately. I said I could give the topic of Postman together with the topic of phone. I taught the Postman song. They already learn by repetition.

During the observations, teachers' feedback was limited to verbal reinforcement like "Well done?" or "Nice work!" Rather than encouraging the children to notice their mistakes and correct them, teachers pointed out their mistakes directly and told them how to correct them. T2, T4, and T8 did not give any feedback and scolded the children when they made mistakes.

At the end of activities, most teachers evaluated the day briefly by talking and discussing what they had done during the day. For example, T3 asked each child to state what they had done and what they had learned. T9 wanted the children to sit in a circle and talk about why they chose the activities and what they did. In the interviews, these teachers also stated that they set aside time for evaluation each day. T2, T4, and T8 did not evaluate the activities. T4 stated that she evaluated student work by saying "Everything is beautiful" and then hanging their work on the wall. However, she did not actually do what she said during the observation.

\section{Category 2: Activities based on voluntary participation}

Most teachers said that they enhanced the children's participation using songs, fingerplay conversations, and task assignments. For example:

T7: I try to make activities more fun to encourage their participation, but in some cases, this does not work. If it is possible, we enable participation by calling on them, getting their attention, using different materials, and arousing their curiosity.

In the observations, $\mathrm{T} 4$ and $\mathrm{T} 8$ did not give their attention to children who did not want to participate. T4 limited children's participation in activities if they showed problem behaviors. T4 and $\mathrm{T} 8$ also stated that they only talked about activities briefly with the children who participated in activities.

When children did not want to participate in activities, T1, T5, and T9 tried to understand why. After that, they provided some alternatives and took the children's decisions into account. These teachers' views were also compatible with their behaviors. Even if the other teachers did not force children who did not want to participate, they did not try to understand their reasons or provide any alternatives. They only paid attention to the children who participated in activities. If some children did not want to join activities, the teachers remarked that they wanted the children to stop (T4, T6, T7, and T8), to complete the activity at home (T10), or to wait in a corner (T8). T2 and T3 stated that 
they wanted children to choose other activities. However, T2 did not give any alternatives to those children and generally ignored them.

T5: I talk with children who do not want to participate. I try to learn the reasons. If there is a solution, I apply it. But I do not force them much.

T9: I do not force them, definitely. If s/he wants to tell me why s/he doesn't want to participate, I listen. Then, s/he does whatever s/he wants. I believe that s/he will get involved later.

\section{Category 3: Child-friendly activities}

Most teachers did not discriminate among the children based on their genders, religions, languages, races, or other personal characteristics. However, T1, T4, and T8 discriminated against children who misbehaved. For example, T4 used some humiliating words when talking about a child with special needs in the next classroom. Also, she did not allow one girl, who was very active in class activities, to participate; she threatened the girl, saying that she would not be liked by the teacher or other children if she did not sit down quietly. T1 and T8 also showed similar responses to misbehaviors.

During observations, most teachers guided children when they needed help without directing them, as they stated. However, T2, T4, and T8 directly told them the right answer or were not interested in helping them. In the interviews, T2 and T4 also noted that they wanted children to quit tasks when they could not complete activities. T8 said that she tried to encourage them to accomplish their tasks with little help. T1 stated the following:

T1: When s/he has difficulty, I guide her/him. As soon as I realize s/he can do it alone, I stop guiding him/her. I know s/he still requires my help, but no. I know my student can do it. To support their self-confidence, I always say "Well done: you can do it".

Most of the teachers answered children's questions and gave importance to their ideas (T1, T5, T6, T7, T9, and T10). These teachers generally tried to answer children's questions by encouraging them to think through the possible answers together and listened to their ideas carefully. The other teachers seemed to be not sufficiently careful about answering children's questions and generally ignored children's questions and ideas.

Most teachers were not sensitive to meeting the needs and incorporating the interests of the children. They generally followed the daily schedule. Only T9 was more sensitive about addressing children's needs and interests. For example, one child in T3's class wanted to go outside, saying that he was bored and wanted fresh air. T3 refused his request and said that he could go outside after the evaluation of their activities. When one child from T8's class could not write the letter A correctly, T8 said, "You don't have to write it, honey. You will come to kindergarten again next year. You will learn it next year". The child insisted on writing it, but she rebuffed his interest and turned her attention to the other children's worksheets.

T1, T3, and T9 remarked that play was very important to children's development. The other teachers also reported that children learn through play (T2, T4, T5, and T10), that it is a way to express themselves (T6, T7, and T8), and that it is one of the rights of the 
child (T3 and T9). It can be concluded that these teachers know the importance of play. Most teachers said that children could play anytime they wanted, except T1, T4, and T10, who stated that they allowed children to play only during rest time.

T2: Of course, I support this. I think the best learning style occurs through play. Sharing... First, I ask the children if we can play... They play as much as they want. T4: I allow them to play with playdough and jump ropes during rest time.

During the observations, researchers noticed that teachers generally saw play as a prize or rest time activity and did not reserve special time for play in their daily schedules (T2, T3, T5, T6, T7, and T10). T1, T4, and T8 did not allow children to play in any way and generally limited their play.

Questions about child abuse were asked to determine what the teachers knew about this subject. T5, T6, and T9 stated that they would talk with the school administration as well as the family of a child who was abused; they also would notify police, social workers, and the guidance service in their schools. The other teachers did not know what they would do or where they should go in such a situation.

\section{Category 4: Positive interactions with children}

Most teachers (T2, T5, T6, T7, T9, and T10) generally tried to talk to and solve problems with children in a calm, mild, and good-humored tone. However, T1, T3, T4, and T8 were not so calm and affectionate toward the children, and their tones of voice were harsher when talking to some children who misbehaved. For example, T3's school was expected to take videos of children during activities and send those to the parents. For that reason, T3 always tried to silence the children by warning them in a harsh tone to avoid noise. Apart from this, most teachers talked with children clearly, comprehensibly, and slowly.

While most teachers conversed with the children about some subjects unrelated to the activities, T2, T3, T6, and T7 avoided talking with children during activities and preferred to talk during rest time. T4 generally avoided talking with the children, whether during the activities or rest time, saying that she felt tired or she would retire soon.

It was observed that threats, comparisons, and judgments were common teacher behaviors as methods for solving behavioral problems. In T6, T7, and T9's classrooms, these behaviors were not observed. Other teachers applied these strategies to control children's misbehaviors. For example, T1 angrily threatened two children who played together rather than joining in the current activity that they would not be allowed to go outside. T4 said to one child who did not want to join in any activity that she deserved to be beaten but $\mathrm{T} 4$ was not allowed to.

\section{Category 5: Supporting positive interactions between children}

In the interviews, teachers stated that when they were met with physical, verbal, or emotional violence between children, they tried to solve the problem in ways such as encouraging them to show empathy toward each other ( $\mathrm{T} 1, \mathrm{~T} 8$, and $\mathrm{T} 10)$, encouraging them to talk about and solve their problems together (T7 and T9), discussing the problem with their families and solving it together (T3 and T5), discussing the problem by presenting a case study (T6), and consulting the school's guidance services (T6 and T7). T2 and T4 
did not say anything about preventing violence. As teachers' behaviors were observed in trying to prevent physical, verbal, and emotional violence, it can be said that most of them were careful about it (T3, T5, T6, T7, T8, and T9). For example, T7 immediately intervened between two children who were fighting by asking them why they were fighting. After learning the reason, she asked them to talk with each other and solve the problem. In the end, the whole class briefly discussed the negative effects of the fight. However, T1, T2, and T10 only warned children who were violent toward each other using verbal directions or threats. T4 did not make any attempt or she threatened the children in turn.

When examining teachers' behaviors in terms of whether they supported children spending their time with each other by playing, talking, or building something together, it was seen that $\mathrm{T} 2, \mathrm{~T} 7$, and $\mathrm{T} 9$ supported children spending time together and did not intervene during these times. T2 said that children were ready to spend time with each other and it was not difficult for her to support them in this. T5, T6, and T8 sometimes supported it and sometimes intervened with the children by asking them to listen or to focus on activities. T6 stated that she aimed to prevent any cliques in the classroom by making different groups so that each child could communicate and spend time with all the others. However, she could not spare enough time to do this because of her school's daily schedule. T1, T3, T4, and T10 did not allow children to spend time with each other because of their daily schedules and to avoid noise. While T3 stated that she tried to put the children in groups, she did not do so in practice to prevent noise in her class.

T6: Recently, I realized that one child was always a leader. He sets up a game, and others remain passive. So, every day I made groups with five children, and every day someone different became a leader. Thus, everyone spent time with each other.

\section{Discussion}

In the first phase of this study, 205 ECE teachers' attitudes were analyzed using the Questionnaire for Measuring Attitudes toward the Rights of the Child. It was found that there was no significant difference in attitudes by teachers' age, professional experience, school type, number of children in the class, or having taken a course about the rights of the child. Other studies have also shown that teachers' age (Daniels-Simmonds, 2009; Donmez, 2015; Peker, 2012; Yasar-Ekici, 2014), school type (Peker, 2012), professional experience (Daniels-Simmonds, 2009; Donmez, 2015; Peker, 2012), and history of taking a relevant course (Dogan et al., 2014; Merey, 2013; Yasar-Ekici, 2014) were not associated with any differences in attitudes toward the rights of the child. However, there were differences in teachers' attitudes in terms of their educational background. Teachers who had a bachelor's or master's degree had more positive attitudes than teachers who only had a high school degree. Kor (2013) showed that teachers who had a bachelor's degree were more aware of the rights of the child than teachers who had a high school degree.

The positive attitudes toward the rights of the child of the teachers who participated in this study parallel the findings of other studies that examined teachers' and teacher candidates' attitudes toward the rights of the child (Dogan et al., 2014; Donmez, 2015; Karaman-Kepenekci, 2006; Kasapoglu \& Akyol, 2012; Leblebici \& Celikoz, 2016). Furthermore, it is notable that attitudes toward the rights of the child were positive overall. 
It can be determined that social desirability could influence teachers to report high positive attitudes without the influence of demographic factors. Social desirability is defined as the tendency of teachers to present themselves as responsive to social norms (King \& Bruner, 2000). Ozen (1998) stated that individuals are more affected by social desirability due to their dependence on social norms in collectivist cultures; more interpretive data collection tools like observation, rather than scales, are required to decrease the effects of social desirability. Correia et al. (2020) explained that teachers' roles, which are shaped by their cultures, have an effect on their ideas about children's participation and also on their decisions. Hofstede $(1979,1980,1982,1983)$ defined various cultural dimensions, one of which is individualism vs. collectivism. While individualism is defined as "a situation in which people are supposed to look after themselves and their immediate family only", collectivism is "a situation in which people belong to in-groups or collectivities which are supposed to look after them in exchange for loyalty" (as cited in Hofstede \& Bond, 1984, p. 419). Turkey's culture is defined as collectivist (Kagitcibasi, 2010), and it can be said that the attitudes of teachers who live in Turkey could be influenced by their tendency to seek social approval. In this study, observations and interviews were used to overcome this limitation. In that context, the 10 teachers who volunteered after the first phase joined the second phase, in which their interactions with children were examined in depth by observing their behaviors during observations and eliciting their views in terms of their compatibility with the rights of the child in one-on-one interviews.

In the second phase, it was found that only two teachers' behaviors and views were compatible with the rights of the child. The other eight teachers' views and behaviors were not completely appropriate in terms of being transparent and informative, giving importance to voluntary participation, organizing child-friendly activities, having positive interactions with children, or supporting positive interactions between children. Some teachers even approved of threatening children to handle misbehavior and this shows that these teachers did not consider the protection rights or best interests of the child. These findings show that while the behaviors and the views of some teachers were incompatible with the rights of the child, their attitudes toward the rights of the child were positive. This can be explained by their attitudes not overlapping with their behaviors and views and by the praxis model. The praxis model depends on linking theory and practice (Burridge et al., 2010). Considering their demographic characteristics, it can be said that a lack of information about the rights of the child could be a factor for this incompatibility and for the teachers not linking their attitudes with their practices. Only 75 teachers in the first phase and three teachers in the second phase stated that they had taken a course on the rights of the child. It is found that the absence of knowledge about the rights of the child negatively affects the implementation of the UNCRC (Jerome et al., 2015; Pugh, 2015). Other studies also showed that teachers' attitudes toward the rights of the child and support for the participation of children were negatively influenced by not having taken any course on the rights of the child (Karaman-Kepenekci \& Baydik, 2009; Nesliturk \& Ersoy, 2007). It was noted that out of 80 universities in Turkey with undergraduate programs in ECE, only 22 departments provided courses related to the rights of the child, and those were elective courses (Turkoglu \& Gultekin-Akduman, 2013). In both the National ECE Program (MoNE, 2013) and Qualification Frameworks for ECE (MoNE, 2017), creating a democratic atmosphere, protecting the rights of the 
child, and supporting children's active participation are emphasized. However, when examining MoNE in-service trainings, it is seen that there are no courses directly related to the rights of the child (http://oygm.meb.gov.tr/www/hizmetici-egitim-planlari/icerik/ 28). It can be inferred that teachers did not reflect their attitudes in their interactions with children because of the limited resources provided to them during their learning processes in both their universities and in-service trainings.

Another reason why teachers' behaviors and views did not reflect their attitudes might be related to class sizes. Correia et al. (2020) explained that group size affects teachers' roles in supporting children's participation. The class size of five of the teachers in the second phase was over 20, whereas, according to the MoNE (2014), there should be between 10 and 20 children in a preschool classroom. Exceeding the maximum class size can negatively influence the teacher-child relationship. Teachers who have fewer children in their classrooms spend less time on classroom management problems, leaving them more time to take an interest in the children individually (Barnett et al., 2004). Studies have also shown that children's participation and protection rights are negatively affected by crowded classes and excessive class sizes (Karaman-Kepenekci \& Nayir, 2012; Ozylldırım, 2007). In this study, teachers were sensitive to children's basic needs such as nutrition and protection. However, teachers generally did not consider children's views, support their interactions with each other, or evaluate activities with them afterwards by asking questions or using other authentic evaluation tools to get their views about the activities and to assess their learning. Focusing on structured activities and mostly on the whole class, not individuals or small groups, could prevent teachers from meeting students' needs and supporting their interests by engaging them in activities and eliciting their views, and thus ensuring their rights of participation, provision, and best interests.

In the interviews, teachers stated that they gave importance to the right to play and saw play as a basic need of children, but it was observed that the teachers did not spare enough time for children to play. In their limited time, they also wanted children to play individually or in small, separate groups to avoid noise and mess. Other researchers have also found that teachers limited free play to short activities (Kadim, 2012; Ozdemir, 2016). However, both the UNCRC (1989) and the National ECE Program (2013) emphasize that play is a need and a necessary means of learning for children's proper development and growth. It can be said that having a crowded classroom and preferring teacher-directed and structured activities for the whole class could make it difficult to notice each child's interests and needs. As a result of not meeting children's interests and needs, it is considered that the children's best interests and participation could not be supported adequately by these teachers. In addition, their provision rights could not be supported because not enough attention was given to their views, needs, and interests.

The findings indicated that teachers' classroom management styles could affect their behaviors. Reeve (2009) found that teachers who adopted autonomy-supporting rather than controlling management styles were more sensitive to encouraging and sustaining children's initiative, autonomy, and active involvement in activities. In this study, teachers did not take children's views into account even in subjects directly affecting them, like activities for them to join in. Furthermore, they did not give enough information and feedback about activities. They generally ignored individual interests and needs 
and applied structured practices to the entire classroom. The findings also revealed that the teachers behaved in an authoritarian and protective manner, considering the groups' needs rather than individual needs, which is common in collectivist cultures. Other studies also showed that teachers in Turkey generally adopt authoritative, teachercentered classroom management styles (Akyol, 2011; Koran, 2012). A literature review by Urinboyev et al. (2016) showed that the right to make decisions belonged to teachers while children were perceived as dependent, not experienced enough, undisciplined, and in need of clear order and authoritative guidance. Teachers who adopt authoritarian classroom management styles show controlling and restrictive behaviors. They develop strict prevention measures against children's problem behaviors. Children in these situations are not given the right to explain their ideas, and so their participation is also limited (Bosworth, 1996, as cited in Akman \& Umay, 2007). Teachers' authoritarian methods also did not overlap with the principles of the national program, according to which instruction should be child-centered and children's interests and needs should be considered in all subjects related to children (MoNe, 2013). It can be inferred that teachers do not support children's participation and do not meet children's needs and interests, which are also related to the provision rights and the best interests of the child.

Teachers' attitudes toward protection rights were more positive than their attitudes toward other rights, as they stated in the second phase that they were sensitive to protecting children from violence, abuse, neglect, war, or any maltreatment. In other studies in Turkey, teachers' attitudes toward protection rights were also found to be positive (Donmez, 2015; Fazlioglu, 2007; Peker, 2012). Teachers' sensitivity toward protection rights can also arise from perceptions of children's needs and dependence on adults, as shaped by their collectivist cultures. Akman and Erturk (2011) found that ECE teachers saw children as defenseless innocents and that protecting them was a social duty. Fazlioglu (2007) also stated that a high sensitivity to protection rights could arise from society's protective ideas regarding children. However, teachers in the current study did not know what they should do upon encountering children exposed to violence, abuse, or neglect. Teachers' lack of information about the rights of the child might have led them to not give enough support to their protection rights even if they knew what they are. These findings also indicate that these teachers are unable to properly support the rights of the child to live in a good, safe place as a part of their provision rights and the best interest of the child.

According to the non-discrimination principle, it is necessary to not discriminate between children based on race, language, or gender (UNCRC, 1989). Following this principle, it can be said that teachers in the second phase of the study did not show any discriminatory behaviors based on race, language, or gender. Their interactions with children were generally positive in this regard. They guided children when they needed help, conversed with them after activities, and were expressive and gentle when talking with them if there were no problematic behaviors. While teachers' interactions with children were positive and they did not discriminate based on gender, race, or language, this was not the case when they were met with problematic behaviors. Threats, comparisons with other students, judgment, and punishment (exclusion from activities, friends, or the classroom) were methods commonly used to overcome problematic behaviors in the classroom. Teachers' classroom management styles could influence their behaviors 
vis-à-vis the non-discrimination principle. Research shows that ECE teachers adopted authoritarian approaches like verbal warnings and punishments when they were met with problem behaviors (Ozturk \& Gangal, 2016; Uysal et al., 2010). As observed, teachers' responses to misbehaviors, like exclusion from activities, threatening that children would not be allowed to play with friends, and other punishments, led to the exclusion of children from participating in class activities and interacting with other children. Children who exhibit problematic behaviors cannot adequately benefit from their education as a result of these discriminatory responses and so these responses may negatively affect their participation and protection rights as well as their best interests. In addition, they cannot benefit from activities like other children and so their provision rights may also be ignored.

\section{Conclusion and limitations}

In this study, it was seen that teachers' behaviors and views during classroom activities did not reflect their attitudes toward the rights of the child. Teachers were found to be sensitive to protection rights, but they did not know what to do if they encountered children exposed to violence, abuse, or neglect. Moreover, teachers did not support children's provision rights, as they were not aware of their needs and interests, did not support their interactions with each other, and limited their play. They did not behave consistently with their views on children's right to participation because they did not heed children's ideas, give feedback, or evaluate their activities. All of these findings also show that the best interests of the child are not protected sufficiently in the classroom. Teachers' strategies for coping with problematic behaviors can negatively affect students' participation rights and non-discrimination principles by limiting and interrupting children's learning processes and excluding them from activities, their friends, and the classroom; as Correia et al. (2019) stated, teachers' pedagogically sensitive approaches to children increase their participation. As a result of teachers not considering their rights of growth, development, and participation as well as the principles of non-discrimination, the children's best interests were also ignored. Despite this, the teachers' attitudes toward the rights of the child were found to be positive. The incompatibility between attitudes and behaviors may be a result of the teachers' lack of information and their adoption of traditional teacher-centered classroom management strategies in crowded classrooms. Etchebehere and De León (2020) stated that teachers had difficulties applying the principles of the UNCRC in their educational proposals. To be able to guarantee the rights of children, it is necessary to introduce institutional mechanisms. For that reason, it is not enough to train teachers; it is also important to create strategies for analyzing educational practices. In addition, Urinboyev et al. (2016) emphasized that school culture, teachers' perceptions, and social norms should be changed to implement the rights of the child in school. For protecting the rights of children, it is clear that not only teachers but also administrators and educators who are responsible for training early childhood teachers need to be informed about the rights of the child. Thus, it is suggested that some courses at schools and universities, workshops, seminars, and other informative meetings about what the rights of the child are, how teachers can protect them, and how teachers can reflect children's rights in their practices should be arranged as well as analyzing their strategies in terms of the rights of children. 
Effective protection of children's rights needs a unifying, comprehensive, and rights-based national strategy rooted in the UNCRC and such strategies should be endorsed at the highest levels of government and be linked to national development planning and budgeting (UNCRC, 2003). As the Council of Europe (2016) recommended, children also need to learn about and raise awareness about their rights, and there should be enough resources to enable this. UNICEF (2012) also states that implementation of the UNCRC should be emphasized in domestic law and policy and that there is a need for training and awareness for rights education. While there are some statements about protecting the rights of the child in national documents of Turkey (Ministry of Family \& Social Policies, 2012; MoNE, 2013, 2017), it is apparent that there are some critical challenges remaining in protecting the rights of children like early schooling rates, child poverty, child marriage, and child violence (Ministry of Strategy and Budget, 2018). Early childhood education has long-term effects of reducing child poverty, protecting against violence, and increasing educational attainment (Anderson et al., 2003; Kagitcibasi et al., 2001). Therefore, policymakers should also pay attention to the rights of children by increasing the rate of early childhood schooling and children's participation in all decisions about them, raising awareness about the rights of the child, and protecting the rights of the child everywhere and at all times. Thus, all individuals can realize the importance of supporting the rights of children from the early years and see children as rights holders. The United Nations published 17 sustainable development goals in 2015, and Goal 4 aims to "ensure inclusive and equitable quality education and promote lifelong learning opportunities for all". In this goal, the importance of early childhood education is also emphasized, and it is stated that all children should have access to quality early childhood education and care. In addition, Goal 16 aims to "promote peaceful and inclusive societies for sustainable development, provide access to justice for all and build effective, accountable, and inclusive institutions at all levels". The other goals, like no poverty, zero hunger, good health, well-being, and gender equality, are also related to the rights of the child. However, UNICEF (2019) reported that some critical issues, including early childhood development and access to quality education, will not be achieved because of slow progress on these goals. For that reason, it is recommended that all stakeholders around the world be more sensitive and careful about promoting the rights of the child and that more global actions be taken.

This study is important in that it investigates ECE teachers' behaviors and views related to the rights of the child in their practices as well as their attitudes toward the rights of the child. However, only 10 teachers volunteered for the observations and interviews in the second phase of the study. Further research is recommended that involves more teachers and encourages them to collaborate. Also, teachers' beliefs, knowledge, and ideas about the rights of children were not assessed. A future study could investigate these to reveal what they need in more detail. In addition, the quantitative study was conducted before the qualitative study, which could have affected teachers' behaviors and views. To lessen this effect, the qualitative study was carried out 3 months after the quantitative study. Further research could first collect qualitative data and then quantitative data to handle this limitation. 


\section{Abbreviations}

ECE: Early childhood education; ERG: Education Reform Initiative; AÇEV: Mother-Child Education Foundation; UNCRC: United Nations Convention on the Rights of the Child; UNICEF: United Nations International Children's Emergency Fund; MoNE: Ministry of National Education; OECD: Organisation for Economic Co-operation and Development; T1:Teacher One; T2: Teacher Two; T3: Teacher Three; T4: Teacher Four; T5: Teacher Five; T6: Teacher Six; T7: Teacher Seven; T8: Teacher Eight; T9: Teacher Nine; T10: Teacher Ten.

\section{Supplementary Information}

The online version contains supplementary material available at https://doi.org/10.1186/s40723-021-00083-9.

Additional file 1. The observation and interview forms for evaluating teachers' behaviors and views about rights of children in their practices.

\section{Acknowledgements}

This study was published as a master's thesis by the first author under the supervision of the second author at Hacettepe University, 2017.

\section{Authors' contributions}

The authors are responsible for this research. Both authors have substantially contributed to conceptualizing and designing the study, analyzing the data, writing and revising the manuscript. Both authors read and approved the final manuscript.

\section{Authors' information}

Cagla Banko Bal is Research Assistant of Early Childhood Education, Hacettepe University, Turkey. She has researched on children's rights, anti-bias education and media effects on children.

Tulin Guler Yildiz is Professor of Early Childhood Education, Hacettepe University, Turkey. She has researched and published extensively on science on early childhood, self-control and sustainability since 1999.

\section{Funding}

No finding was sought or received for the research reported here.

\section{Availability of data}

The qualitative datasets used and/or analyzed during the current study are available from the corresponding author on reasonable request.

\section{Declarations}

Competing interests

The authors declares no competing interests.

Received: 9 March 2020 Accepted: 30 April 2021

Published online: 17 May 2021

\section{References}

Akman, B., \& Erturk, H. G. (2011). Okul öncesi öğretmenlerinin çocuk haklarına ilis kin bilgi düzeylerinin ve okul öncesi çocuk haklarının öğretilmesine ili ş kin görüşlerinin incelenmesi. [The Investigation of early childhood teachers' knowledge levels among rights of the child and views for teaching rights of the child] . 1. Türkiye Çocuk Hakları Kongresi Yetişkin Bildiri Kitabı 1. Çocuk Vakfı Yayınları, Istanbul. http://cocukvakfi.org.tr/wp-content/dosya/36k.pdf.

Akman, B., \& Umay, A. (2007). Öğretmenlerinin sınıfyönetimi profillerine yönelik bir ölçek uyarlama çalışması [A scale adaption towards teachers' classroom management profiles]. http://www.egitim.hacettepe.edu.tr/belge/UOYPSS1_Bildi riKitabi.pdf.

Akyol, S. (2011). Çocuk Haklarına Dair Sözleşme çerçevesinde çocuğun görüşlerine saygı ilkesi: Varlığ ın sahibi olan çocuk [Principle of respect for the views of the child within the framework of the Convention on the Rights of the Child: The child who is the owner of the property]. 1. Türkiye Çocuk Hakları Kongresi Yetişkin Bildiri Kitabı 1. Çocuk Vakfı Yayınları, Istanbul. http://cocukvakfi.org.tr/wp-content/dosya/36k.pdf. Accessed 24 May 2019.

Alderson, P. (2008). Young children's rights: Exploring beliefs, principles, and practice. (2nd ed.). Jessica Kingsley Publisher

Anderson, L. M., Shinn, C., Fullilove, M. T., Scrimshaw, S. C., Fielding, J. E., Normand, J., \& Carande-Kulis, V. G. (2003). The effectiveness of early childhood development programs: A systematic review. American Journal of Preventive Medicine, 24, 32-46

Akyuz, E. (2000). Ulusal ve Uluslarası Hukukta Çocuğun Haklarının ve Güvenliğinin Korunması [The Protection of Child's Rights and Safety in National and International Law]. Milli Eğitim Basım Evi

Barnett, W.S., Schulman, K. \& Shore, R. (2004). (2004). Class size: What's the best fit? National Institute for Early Childhood Education Research, http://nieer.org/wp-content/uploads/2016/08/9.pdf.

Bredekamp, S. (2018). Brain development and implications for practice. He Kupu, 5(3), 41-44 
Burridge, P., Carpenter, C., Cherednichenko, B., \& Kruger, T. (2010). Investigating praxis inquiry within teacher education using Giddens'structuration theory. Journal of Experiential Education, 33, 19-37. https://doi.org/10.1177/1053825910 03300103

Correia, N., Camilo, C., Aguiar, C., \& Amaro, F. (2019). Children's right to participate in early childhood education settings: a systematic review. Children and Youth Services Review. https://doi.org/10.1016/j.childyouth.2019.02.031

Correia, N., Carvalho, H., Durães, J., \& Aguiar, C. (2020). Teachers'ideas about children's participation within Portuguese early childhood education settings. Children and Youth Services Review. https://doi.org/10.1016/j.childyouth.2020. 104845

Council of Europe (2016). Council of Europe Strategies for the Rights of the Child (2016-2021): Children Human Rights, https://rm.coe.int/168066 cff8

Covell, K., McNeil, J. K., \& Howe, R. B. (2009). Reducing teacher burnout by increasing student engagement: A Children's Rights approach. School Psychology International, 30(3), 282-290. https://doi.org/10.1177/0143034309106496

Covell, K., \& Howe, R. B. (2011). Rights, respect, and responsibility in Hampshire County: RRR and Resilience Report. Cape Breton University: Children's Rights Centre. http://www.childrensrightseducation.com/uploads/3/4/5/2/34521419/ rights_respect_and_responsibility_2008_report.pdf.

Creswell, J. W. (2017). Karma Yöntem Araştırmalarına Giriş Introduction to Mixed Methods Research (M. Sozbilir, Trans.) Ankara: Pegem Akademi.

Creswell, J. W., \& Plano-Clark, V. (2015). Karma yöntem araştırmaları: Tasarımı ve yürütülmesi [Designing and conducting mixed methods research] (Y. Dede \& S. B. Demir, Trans.). Ankara: Anı Yayıncilık.

Daniels-Simmonds, L. (2009). Early childhood professionals' beliefs and practices regarding the rights of young children to express views and to be heard (Unpublished doctoral dissertation). Texas Women's University.

Dogan, Y., Torun, F., \& Akgun, IH. (2014). Pre-school teacher candidates'attitudes towards children's rights in terms of some variables. Journal of Human Sciences, 11(2), 503-516. https://doi.org/10.14687/ijhs.v1 1i2.2998

Donmez, T. (2015). Illkokul Sınıf Öğretmenlerinin Sınıf Yönetimi Profilleri lle Çocuk Haklarına Yönelik Tutumları Arasındaki llişki [The Relationship Between Classroom Management Profiles of Primary School Teachers and Their Attitude towards Children Rights] [Unpublished master's thesis]. Gazi University, Ankara

ERG \& AÇEV (2017). Türkiye'de Erken Çocukluk Bakımı ve Okul Öncesi Eğitime Katılım [Turkey in the Early Childhood and PreSchool Education]. http://www.egitimreformugirisimi.org/yayin/turkiyede-erken-cocukluk-bakimi-ve-okul-oncesiegitime-katilim/\#more-8050

Etchebehere, G., \& De León, D. (2020). Children's rights in the field of early education. Early Years. https://doi.org/10.1080/ 09575146.2020 .1825340

Erden, M. (2005). Öğretmenlik mesleğine giriş[Introduction to the teaching profession]. Epsilon Yayıncılık.

Fazlioglu, Z. (2007). Çocuk Hakları Sözleşmesi'nde Yer Alan Çocuk Hakları Konusunda Öğretmenlerin ve Yöneticilerin Bilinç Düzeyleri [Awareness levels of teachers and managers on the rights of the child in the convention on the rights of the child] [Unpublished master's thesis]. Yeditepe University.

George, D., \& Mallery, P. (2003). SPSS for Windows step by step: A simple guide and reference. 11.0 update. (4th ed.). Allyn \& Bacon.

Hareket, E., \& Gulhan, M. (2016). Perceptions of students in primary education department related to children's rights: A comparative investigation. Journal of Education and Learning. https://doi.org/10.5539/jel.v6n2p41

Hofstede, G., \& Bond, M. H. (1984). Hofstede's Culture Dimensions: An Independent Validation Using Rokeach's Value Survey. Journal of Cross-Cultural Psychology, 15(4), 417-433. https://doi.org/10.1177/0022002184015004003

Howe, R. B., \& Covell, K. (2005). Empowering children: Children's rights education as a pathway to citizenship. University of Toronto Press.

Jerome, L. Emerson, L. Lundy, L. \& Orr, K. (2015). Teaching and learning about children's rights. London: UNICEF. https:// www.unicef.org/media/63086/file/UNICEF-Teaching-and-learning-about-child-rights.pdf

Johnson, B., \& Christensen, L. (2014). Eğitim Arastırmaları: Nicel, Nitel Ve Karma Yaklasıımlar [Educational Research: Quantitative, Qualitative and Mixed Approaches] (S. B. Demir, Trans. \& Ed.). Ankara: Eğiten Kitap.

Kadim, M. (2012). Okul öncesi öğretmenlerinin oyun etkinliklerine ilişkin öz-yeterliklerinin görev yapilan okul türüne göre incelenmesi [Examine the preschool teachers'self- efficacy about the game activities according to the type of school]. NEÜ Sosyal Bilimler Enstitüsü Dergisi, 2, 1-21.

Kagitcibasi, Ç. (2010). Benlik, Aile ve linsan Gelişimi: Kültürel Psikoloji [Self, family and human development: Cultural psychology. Koc Universitesi Yayinlari.

Kagitcibasi, C., Sunar, D., \& Bekman, S. (2001). Long-term effects of early intervention: Turkish low-income mothers and children. Journal of Applied Developmental Psychology, 22, 333-361

Karaman-Kepenekci, Y. (2006). A study of university students'attitudes towards children's rights in Turkey. The International Journal of Children's Rights, 14, 307-319. https://doi.org/10.1163/157181806778458095

Karaman-Kepenekci, Y., \& Baydık, B. (2009). Zihin engelliler öğretmen adaylarının çocuk haklarına ilişkin tutumları [Attitudes of the teacher candidates of mentally handicapped children about children's rights]. Ankara Üniversitesi Eğitim Bilimleri Fakültesi Dergisi, 42(1), 329-350

Karaman-Kepenekci, Y., \& Nayır, F. (2012). Çocukların ana babaları tarafından istismar ve inmaline ilişkin sınıf öğretmenlerinin görüşleri [Elementary school teachers' perceptions about child abuse and neglect by their parents]. International Journal of Social Science, 5(7), 437-455. https://doi.org/10.9761/JASSS_274.

Kasapoglu, K., \& Akyol, T. (2012). Liking of children as a predictor of their attitudes toward Children's Right. The New Educational Review, 28(29), 49-58

Kepenekci, Y. (1999). Eğitimcilerin insan haklarına yönelik tutumları [Educators'attitudes towards human rights]. Ankara Üniversitesi Eğitim Bilimleri Dergisi, 32.

King, M. F., \& Bruner, G. C. (2000). Social desirability bias: A neglected aspect of validity testing. Psychology and Marketing, 17(2), 79-103. https://doi.org/10.1002/(SICl) 1520-6793(200002)17:2\%3c79::AID-MAR2\%3e3.0.CO;2-0

Kor, K. (2013).Okul Öncesi Öğretmenlerin Çocuk Hakları Konusundaki Görüşlerinin Belirlenmesi [The Investigation of the Views of Early Childhood Teachers about the Rights of the Child] [Unpublished master's thesis]. Canakkale Onsekiz Mart University, Canakkale 
Koran, N. (2012). Sınıflarda Katılım Hakkı: Okul Öncesi Öğretmenlerinin Çocukların Katılım Hakkı Konusundaki Uygulamalarının Öğretmen Adayı Gözlemlerine Göre Incelenmesi [Participation Right in Classrooms: The Understanding of Participation Right of Early Childhood Teachers'and Supporting the Understanding of Participation Right of Early Childhood Teachers'] [Unpublished master's thesis]. Girne American University, Girne.

Landsdown, G. (2005). Innocent insight: The evolving capacities of the child. UNICEF Innocenti Preseed Centre, Florence, Italy. https://www.unicef-irc.org/publications/pdf/evolving-eng.pdf, Accessed 24 May 2019.

Leblebici, H., \& Celikoz, N. (2016). Öğretmen adaylarının çocuk haklarına yönelik tutumları [Prospective teachers' attitudes towards children rights]. International Journal of Social Sciences and Education Research, 3(1), 307-318. https://doi. org/10.24289/ijsser.270584

Malmberg, L. E. (2008). Student teachers achievement goal orientation during teacher studies: Antecedents, correlates, and outcomes. Learning and Instruction, 18(5), 438-452. https://doi.org/10.1016/j.learninstruc.2008.06.003

Merey, Z. (2013). Social studies pre-service teachers'attitudes towards children's rights. Eğltimde Kuram Ve Uygulama, 9(3), 243-253

Miles, M. B., \& Huberman, A. M. (1994). Qualitative data analysis: An expanded sourcebook. (2nd ed.). Sage.

Ministry of Family and Social Policies. (2012). Ulusal Çocuk Hakları Strateji Belgesi ve Eylem Planı, 2013-2017 [National Strategy Document and Action Plan for Rights of Children, 2013-2017]. https://www.ailevecalisma.gov.tr/uploads/ chgm/uploads/pages/yayinlar/ulusal-cocuk-haklari-strateji-belgesi-ve-eylem-plani.pdf.

Ministry of Strategy and Budget (2018). On Birinci Kalkinma Plani (2019-2023) [11th Development Plan (20192023)].https://www.sbb.gov.tr/wpcontent/uploads/2019/07/OnbirinciKalkinmaPlani.pdf

MoNE. (2013). Okul Öncesi Eğitim Programı [Early Childhood Education Program]. https://tegm.meb.gov.tr/dosya/okulo ncesi/ooproram.pdf.

MoNE. (2014). Milli Eğitim Bakanlığı Okul Öncesi Eğitim ve Ilköğretim Kurumları Yönetmeliği [MoNE Institution Regulation for Early Childhood Education and Primary Education]. http://mevzuat.meb.gov.tr/dosyalar/1703.pdf.

MoNE. (2017). Okul Öncesi Öğretmeni Özel Alan Yeterlikleri [ECE Teachers Special Field Qualifications].https://oygm.meb. gov.tr/meb_iys_dosyalar/2017_11/06160307_5-YYretmen_Yeterlikleri_KitabY_okul_Yncesi_YYretmeni_Yzel_alan_ yeterlikleri_ilkYYretim_parYa_8.pdf

MoNE. (2020). 2019-2020 Eğitim-Öğretim Ylı Istatistikleri [Teaching-Learning Statictics for 2019-2020]. http://ankara. meb.gov.tr/www/egitim-istatistikleri/icerik/24

Nah, K.O. \& Lee, S.M. (2016). Actualizing children's participation in the development of outdoor play areas at an early childhood institution. Action Research, 14(3), 335-351. https://doi.org/10.1177/1476750315621610

Nesliturk, S., \& Ersoy, A. F. (2007). Okul öncesi öğretmen adaylarının çocuk haklarııı öğretimine ilişkin görüşleri [Preschool teacher candidates' opinions on the teaching of children's rights]. Eğitimde Kuram Ve Uygulama, 3(2), 245-257

Osler, A., \& Starkey, H. (1998). Children's rights and citizenship: Some implications for the management of schools. International Journal of Children's Rights, 6, 313-333

Ozdemir, S. (2016). 5-6 yas grubu çocukların serbest zaman etkinliklerindeki oyun ve oyuncak tercihlerinin incelenmesi [Examining the games and toys choices of children aged 5 to 6 at their free time activities]. Journal of Educational Science, 2(2), 1-15

Ozen, S. (1998). Örgütsel araştırmalardaki sosyal beğenirlik etkisinin türk toplumsal ve bürokratik kültürü bağlamında incelenmesi [The investigation of the social desirability effect in organizational research in the context of Turkish social and bureaucratic culture]. VI. Ulusal Yönetim ve Organizasyon Kongresi Bildirileri, 107-121, 21-23 May 1998. Eskişehir: Anadolu University.

Oztürk, Y., \& Gangal, M. (2016). Okul öncesi eğitim öğretmenlerinin disiplin, sınıf yönetimi ve istenmeyen davranışlar hakkındaki inançları [Preschool teachers' beliefs about discipline, classroom management, and disruptive behaviors]. Hacettepe Üniversitesi Eğitim Fakültesi Dergisi, 31(3), 593-608. https://doi.org/10.16986/HUJE.2016015869

Ozyıldııım, T. (2007). Ankara ili ilköğretim okulu öğrencilerinin katılım hakkını kullanma durumlarına ilıskin sınıf ögretmenlerinin görüşleri [The opinions of primary school teachers related to the usage of the participation rights of primary school students] [Unpublished master thesis]. Ankara University, Turkey.

Peker, R. (2012). Sınıföğretmenlerinin demokratik tutumları ile çocuk haklarına yönelik tutumlarının değerlendirilmesi: Manisa ili örneği [The assesment of te class teachers democratic attitudes and attitudes regarding childrens rights (Case Manisa)] [Unpublished master thesis]. Mehmet Akif Ersoy University, Burdur

Pianta, R. C., \& Walsh, D. J. (1996). High risks children in schools: constructing sustaining relationships. Routledge.

Pugh, G. (2015). Early childhood services in England: policy, research, and practice. In A. Smith (Ed.), Enhancing children's rights: connecting research, policy and practice (studies in childhood and youth). (pp. 65-79). Palgrave Macmillan.

Quennerstedt, A. (2011). The construction of children's rights in education - a research synthesis. International Journal of Children's Rights, 19(4), 661

Reeve, J. (2009). Why teachers adopt a controlling motivating style toward students and how they can become more autonomy supportive. Educational Psychologist, 44(3), 159-175. https://doi.org/10.1080/00461520903028990

Reijntjes, A., Stegge, H., \& Terwogt, M. M. (2006). Children's coping with peer rejection the role of depressive symptoms, social competence, and gender. Infant and Child Development, 15, 89-107. https://doi.org/10.1002/icd.435

Shier, H. (2001). Pathways to participation: Openings, opportunities, and obligations. Children and Society, 10, 107-117. https://doi.org/10.1002/chi.617

Sebba, J., \& Robinson, C. (2010). Evaluation of UNICEF UK's Rights Respecting Schools Award.https://www.unicef.org.uk/right srespectingschools/wpcontent/uploads/sites/4/2014/12/RRSA_Evaluation_Report.pdf.

Trawick-Smith, J. (2010). Early childhood development: A multicultural perspective. (5th ed.). Pearson.

Turkish Statistical Institute. (2020). Adrese Dayalı Nufüs Kayıt Sistemi Sonuçları [Address Based Population Registration System Results], 2019. https://data.tuik.gov.tr/Bulten/Index?p=Adrese-Dayali-Nufus-Kayit-Sistemi-Sonuc lari-2019-33705

Turkoglu, D., \& Gultekin-Akduman, G. (2013). Üniversitelerin okul öncesi eğitimi programlarında "çocuk hakları" dersi ve öğrenci görüșlerinin incelenmesi. Uluslararası Aile Çocuk Ve Eăitim Dergisi, 1(2), 56-68

Ucus, S. (2014). Çocuk hakları eğitimi programının hazıllanması ve değerlendirilmesi: uygulama öğretmeninin ve katılımcıların görüşleri [Preparation and evaluation of children's rights education program: the opinions of 
curriculum practitioner and the opinions of participiants]. International Journal of New Trends in Arts, Sports \& Science Education, 3(2), 1-24

UN. (2015). The 17 Goals. https://sdgs.un.org/goals.

UNCRC (1989). Convention on the Rights of the Child. https://www.ohchr.org/en/professionalinterest/pages/crc.aspx.

UNCRC (2003). General Comment No. 5: General Measures of Implementation of the Convention of the Rights of the Child. https://www.refworld.org/docid/4538834f11.html

UNCRC. (2005). General Comment No.7: Implementing Child Rights in Early Childhood. https://www.refworld.org/docid/ $460 \mathrm{bc5a62} . \mathrm{html}$.

UNESCO. (2010). Moscow Framework For Action and Cooperation: Harnessing the Wealth of Nations. World Conference on Early Childhood Care and Education. Moscow. https://unesdoc.unesco.org/ark:/48223/pf0000189882

UNICEF. (2009). Child-Friendly School Manual. https://www.unicef.org/publications/index_49574.html, Accessed 9 November 2017.

UNICEF (2012). The UN Convention on the Rights of the Child: A Study of Legal Implementation in 12 countries. United Kingdom. https://www.unicef.org.uk/publications/child-rights-convention-2012-report/.

UNICEF (2014). Child Rights Toolkit. https://www.unicef.org/eu/crtoolkit/toolkit.html. Accessed 9 November 2017.

UNICEF. (2019). For every child, reimagine: UNICEF Annual Report 2019. New York: United Nations Children's Fund (UNICEF), 2020.

Urinboyev, R., Wickenberg, P., \& Leo, U. (2016). Child Rights, classroom, and school management: A systematic literature review. International Journal of Children's Rights, 24, 522-547. https://doi.org/10.1163/15718182-02403002

Uysal, H., Akbaba-Altun, S., \& Akgun, E. (2010). The strategies preschool teachers use when confronted with children's undesired behaviors. Elementary Education Online, 9(3), 971-979

Wolcott, H. F. (1990). Writing up qualitative research. Sage.

Yasar-Ekici, F. (2014). Öğretmen adaylarının çocuk haklarına yönelik tutumlarının bazı değişkenlere göre incelenmesi [Examining prospective teachers'attitudes towards child rights in terms of some variables]. Akademik Sosyal Araştırmalar Dergisi, 2(8), 66-77.

Yoleri, S. (2014). Okul öncesi ögretmenlerinin çocuk sevme düzeyine etki eden değişkenlerin incelenmesi[The investigating the effects of the variables on early childhood teachers'level of child likehood]. International Eurasian Educational Research Congress, April 24-26, Istanbul University Congression Center.

\section{Publisher's Note}

Springer Nature remains neutral with regard to jurisdictional claims in published maps and institutional affiliations.

\section{Submit your manuscript to a SpringerOpen ${ }^{\circ}$ journal and benefit from:}

- Convenient online submission

- Rigorous peer review

- Open access: articles freely available online

- High visibility within the field

- Retaining the copyright to your article

Submit your next manuscript at $\boldsymbol{\Delta}$ springeropen.com 